\title{
Expression and activation of the oxytocin receptor in airway smooth muscle cells: Regulation by TNF $\alpha$ and IL-13
}

Yassine Amrani ${ }^{2,4^{*}+}$, Farhat Syed ${ }^{1 \dagger}$, Chris Huang ${ }^{1}$, Katherine Li ${ }^{1}$, Veronica Liu', Deepika Jain ${ }^{2}$, Stefan Keslacy ${ }^{2}$, Michael W Sims ${ }^{2}$, Hasna Baidouri ${ }^{2}$, Philip R Cooper ${ }^{2}$, Hengjiang Zhao ${ }^{2}$, Salman Siddiquii ${ }^{4}$ Christopher E Brightling ${ }^{4}$, Don Griswold ${ }^{1}$, Lily Li ${ }^{3}$, Reynold A Panettieri $\mathrm{Jr}^{2}$

\begin{abstract}
Background: During pregnancy asthma may remain stable, improve or worsen. The factors underlying the deleterious effect of pregnancy on asthma remain unknown. Oxytocin is a neurohypophyseal protein that regulates a number of central and peripheral responses such as uterine contractions and milk ejection. Additional evidence suggests that oxytocin regulates inflammatory processes in other tissues given the ubiquitous expression of the oxytocin receptor. The purpose of this study was to define the role of oxytocin in modulating human airway smooth muscle (HASMCs) function in the presence and absence of IL-13 and TNF $\alpha$, cytokines known to be important in asthma.
\end{abstract}

Method: Expression of oxytocin receptor in cultured HASMCs was performed by real time PCR and flow cytomery assays. Responses to oxytocin was assessed by fluorimetry to detect calcium signals while isolated tracheal rings and precision cut lung slices (PCLS) were used to measure contractile responses. Finally, ELISA was used to compare oxytocin levels in the bronchoalveloar lavage (BAL) samples from healthy subjects and those with asthma.

Results: PCR analysis demonstrates that OXTR is expressed in HASMCs under basal conditions and that both interleukin (IL)-13 and tumor necrosis factor (TNF $\alpha$ ) stimulate a time-dependent increase in OXTR expression at 6 and $18 \mathrm{hr}$. Additionally, oxytocin increases cytosolic calcium levels in fura-2-loaded HASMCs that were enhanced in cells treated for $24 \mathrm{hr}$ with IL-13. Interestingly, TNF $\alpha$ had little effect on oxytocin-induced calcium response despite increasing receptor expression. Using isolated murine tracheal rings and PCLS, oxytocin also promoted force generation and airway narrowing. Further, oxytocin levels are detectable in bronchoalveolar lavage (BAL) fluid derived from healthy subjects as well as from those with asthma.

Conclusion: Taken together, we show that cytokines modulate the expression of functional oxytocin receptors in HASMCs suggesting a potential role for inflammation-induced changes in oxytocin receptor signaling in the regulation of airway hyper-responsiveness in asthma.

\section{Introduction}

Oxytocin, a hypothalamic neuropeptide, induces uterine contractions during parturition and milk ejection during lactation via activation of the oxytocin receptor, a $G$ protein-coupled receptor [1]. Prior to the onset of labor, uterine muscle becomes exquisitely sensitive to oxytocin

\footnotetext{
* Correspondence: ya26@le.ac.uk

+ Contributed equally

${ }^{2}$ Pulmonary, Allergy and Critical Care Division, Department of Medicine, University of Pennsylvania, TRL Suite 1200, 125 South 31st Street, Philadelphia, PA 19104, USA
}

due to dramatic increases in the expression of oxytocin receptors (OXTR) [2] whose activation promotes myometrial shortening. Recently, the role of oxytocin has expanded given the discovery of OXTR gene expression in diverse tissues such as the pituitary, kidney, ovary, testis, thymus, heart, vascular endothelium, osteoclasts, myoblasts, pancreatic islets, adipocytes, several types of cancer cells [1], smooth muscle and epithelial compartment of the human epididymis [3]. Evidence also suggests oxytocin may serve as an acute phase response 
protein after injury [1]. Whether oxytocin plays a role in lung diseases remains unknown.

Asthma, a chronic disorder with a genetic and an environmental component [4], manifests as reversible airway obstruction, airway hyper-responsiveness, inflammation and remodeling. Asthma affects an estimated 15 million Americans, and asthma morbidity and mortality continues to rise globally [5]. Airway inflammation associated with the mucosal infiltration of $\mathrm{T}$ helper $(\mathrm{Th})$ 2 subset of $\mathrm{CD} 4^{+} \mathrm{T}$ cells and eosinophils [6,7] evokes the production of various pro-inflammatory mediators involved in the pathogenesis of asthma [5]. Evidence suggests that the incidence of asthma exacerbations during pregnancy occurs in about $20 \%$ of women $[8,9]$. Why asthma may worsen during pregnancy in some women remains unclear. The role of gonadal hormones in altering lung function during pregnancy has been proposed as a possible explanation for asthma morbidity in pregnancy $[10,11]$. A direct action of estrogen on airway smooth muscle function has been recently reported as a plausible molecular mechanism linking sex hormone and disease worsening [12]. Other circulating pregnancy-associated factors also exert detrimental effects on asthma by modulating airway smooth muscle function. Evidence suggests that oxytocin can act as a potent immune-modulary factor in animal models of myocardial infarction [13], atherosclerosis [14] or pyelonephritis [15]. Although the oxytocin receptor is expressed in the lungs [16], whether oxytocin plays a role in airway diseases remains unknown.

Of the resident airway tissues, airway smooth muscle, a target and/or producer of inflammatory cytokines, represents the pivotal tissue regulating bronchomotor tone $[17,18]$. We postulate that oxytocin modulates airway smooth muscle shortening and that pro-inflammatory cytokines, interleukin (IL)-13 and tumor necrosis factor TNF $\alpha$, may amplify oxytocin's effects on airway smooth muscle [19]. Previous studies demonstrate that calcium mobilization induced by oxytocin in human myometrial cells was enhanced with TNF $\alpha$ treatment [20]. This is an interesting finding since we have also shown that TNF $\alpha$ amplifies calcium responses evoked by other agonists including carbachol, bradykinin and histamine $[21,22]$. Others, using murine models of allergen-induced inflammation, have implicated TNF $\alpha$ and IL-13 in promoting airway hyper-responsiveness inflammation and mucus hyper-secretion [23-27].

Here, we report the expression and function of oxytocin receptor in airway smooth muscle (both in human and mouse); more importantly, we also report that oxytocin receptor expression is affected by IL-13 and TNFa. In addition, measurable oxytocin levels are found in BAL fluid in healthy subjects and those with asthma. Although the clinical relevance of these findings remains to be determined, the ability of cytokines to evoke oxytocin responses raises a novel hypothesis that expression or coupling of oxytocin receptors, not oxytocin levels per se, in the airways promotes airway hyperresponsiveness.

\section{Materials and methods \\ Subjects}

Subjects with asthma and healthy controls were recruited from Glenfield Hospital outpatients, staff, and by local advertising. Asthma was defined by one or more of the following objective criteria: significant bronchodilator reversibility of $\mathrm{FEV}_{1}>200 \mathrm{ml}$, a provocation concentration of methacholine causing a $20 \%$ fall in $\mathrm{FEV}_{1}\left(\mathrm{PC}_{20}\right)$ of less than $8 \mathrm{mg} / \mathrm{ml}$ or a peak flow amplitude \% mean over 2 weeks of more than $20 \%$. Asthma severity was classified using the current GINA guidelines based upon the GINA treatment steps (GINA guideline). Normal subjects had no history of respiratory disease and normal spirometry and methacholine responsiveness. All subjects were non-smokers with a past smoking history of less than 10 pack years. The Leicestershire Ethics Committee approved the study and all patients gave their written informed consent.

\section{Protocol and clinical measurements}

Subjects attended on two occasions. At the first visit, spirometric parameters before and after bronchodilator (400 $\mu \mathrm{g}$ inhaled albuterol) and methacholine airway responsiveness using the tidal breathing method (0.03 to $16 \mathrm{mg} / \mathrm{ml}$ ) were determined. At the second visit 1 week later, the subjects underwent bronchoscopy and a $180 \mathrm{ml}$ BAL into the middle lobe. The BAL was centrifuged and the cell-free supernatant stored at $-80^{\circ} \mathrm{C}$ for later analysis.

\section{Oxytocin assay}

Oxytocin levels in BAL samples from asthmatic and healthy subjects were assayed using a competitive enzyme immunoassay kit (ELISA) from Assay Designs, Inc. catalog no. 901-153 (Ann Arbor, MI, USA). Assay procedure and calculation of the concentration of oxytocin were performed using the protocol provided by the kit. Briefly, $100 \mu \mathrm{l}$ of all standards and BAL samples were loaded in triplicate with $50 \mu \mathrm{l}$ of blue conjugate antibody into each well, except the total activity and blank wells. The plate was sealed and incubated at $4^{\circ} \mathrm{C}$ for $24 \mathrm{hr}$. After incubation, wells were washed 3 times, and pNpp substrate solution was added and incubated at room temperature for $1 \mathrm{hr}$. Subsequently, the plates were read immediately at an optical density of $405 \mathrm{~nm}$. The concentration of oxytocin in the samples was calculated based on the standard curve obtained with known concentrations of oxytocin provided in the kit. 


\section{Human airway smooth muscle cell culture}

Human tracheae were obtained from lung transplant donors, in accordance with procedures approved by the University of Pennsylvania Committee on Studies Involving Human Beings. A segment of trachea just proximal to the carina was removed under sterile conditions and the tracheal muscle was isolated. Enzymatic dissociation of the tissue was performed for $90 \mathrm{~min}$ in a shaking water bath at $37^{\circ} \mathrm{C}$. The cell suspension was filtered through $105 \mu \mathrm{m}$ Nytex mesh, and the filtrate was washed with equal volumes of cold Ham's F12 medium (Gibco BRL Life Technologies, Grand Island, NY) supplemented with 10\% FBS (HyClone, Logan, UT), $100 \mathrm{U} /$ $\mathrm{ml}$ penicillin (Gibco), $0.1 \mathrm{mg} / \mathrm{ml}$ streptomycin (Gibco), and $2.5 \mu \mathrm{g} / \mathrm{ml}$ fungizone (Gibco). Aliquots of the cell suspension were plated at a density of $1 \times 104$ cells/ $\mathrm{cm} 2$. The cells were cultured in Ham's F12 media supplemented with $10 \% \mathrm{FBS}, 100 \mathrm{U} / \mathrm{ml}$ penicillin, $0.1 \mathrm{mg} /$ $\mathrm{ml}$ streptomycin and this was replaced every $72 \mathrm{hr}$. Human ASM cells in subculture during the second through fifth cell passages were used. Primary human airway smooth muscle cells from "normal" donors were cultured with IL-13 or a naturally occurring mutant form IL13R130Q (50 ng/ml) or TNF $\alpha(10 \mathrm{ng} / \mathrm{ml})$ for 0 , 6 or $18 \mathrm{hr}$ after resting the cells for $24 \mathrm{hr}$.

\section{Reverse transcription and real time PCR}

Real time PCR was performed to assess whether oxytocin receptor expression was modulated by pro-inflammatory cytokines, TNF $\alpha$, IL- 13 and IL-13R130Q, a naturally occurring isoform of IL-13 and associated with high serum IgE levels [28]. Total RNA was isolated using the RNeasy mini kit (Qiagen, Inc., Valencia, CA) as per manufacturer's instructions. $1 \mu \mathrm{g}$ of total RNA was reverse transcribed as per protocol using $\operatorname{TaqMan}^{\oplus} \mathrm{RT}$ reagents (Applied Biosystems) at $37^{\circ} \mathrm{C}$ for $120 \mathrm{~min}$ followed by $25^{\circ} \mathrm{C}$ for $10 \mathrm{~min}$. Forty ng of cDNA per reaction was used in the real time PCR using the ABI Prism ${ }^{\circledR} 7900 \mathrm{HT}$ Sequence Detection System (Foster City, CA). In the presence of AmpliTaq Gold DNA polymerase (ABI Biosystems, Foster City, CA), the reaction was incubated for 2 $\min$ at $50^{\circ} \mathrm{C}$ followed by $10 \mathrm{~min}$ at $95^{\circ} \mathrm{C}$. Then the reaction was run for 40 cycles at $15 \mathrm{sec}, 95^{\circ} \mathrm{C}$ and $1 \mathrm{~min}, 60^{\circ} \mathrm{C}$ per cycle. Assays-on-Demand ${ }^{\mathrm{Tm}}$ primers and probes specific for oxytocin receptor (Applied Biosystems; ID number Hs00168573_m1) were used in the PCR. The endogenous $18 \mathrm{~S}$ rRNA was measured and used to normalize all samples using the $\Delta \Delta C T$ method (Applied Biosystems). Gene expression level of OXTR is expressed relative to $18 \mathrm{~S}$ and untreated samples in each stimulation study, respectively. At least 3 (often 6) replicates were run for each condition. Student T-test was conducted between a pair of treatment conditions to determine if the observed difference in expression value was statistically significant, use $\mathrm{p}<0.05$ as threshold.

\section{Flow cytometry}

Flow cytometry was performed to determine whether cytokine-induced changes in receptor mRNA expression is associated with changes in protein expression as described previously with slight modifications [29]. Briefly, adherent cells treated with $50 \mathrm{ng} / \mathrm{nl} \mathrm{IL-13}$ or $10 \mathrm{ng} / \mathrm{ml}$ TNF $\alpha$ for $24 \mathrm{hr}$ were washed with PBS, detached by trypsinization $\left(2 \mathrm{~min}, 37^{\circ} \mathrm{C}\right)$ and then washed with Ham's-F12 (10\% FCS) media, centrifuged, and transferred to microfuge tubes $(1.5 \mathrm{ml})$. Cells were resuspended in fixation medium $\mathrm{A}$ and then permeabilization medium B (Caltag, Burlingame, CA). Cells were then incubated with either control isotype of goat polyclonal anti-human oxytocin receptor antibody $(2 \mu \mathrm{g} / \mathrm{ml}$, Santa Cruz Biotech., CA), washed, and followed by $1 \mathrm{hr}$ incubation with a fluorescein isothiocyanate-conjugated secondary antibody (1:100, Jackson ImmunoResearch Laboratories, West Grove, PA). The cells were then centrifuged and resuspended in cold PBS in microfuge tubes. Samples were then analyzed using an EPICS XL flow cytometer (Coulter, Hialeah, FL). Levels of oxytocin receptor were expressed as the percent increase in mean fluorescence intensity over unstimulated cells. Oxytocin levels in the sputum supernatant of asthmatics and healthy control subjects were compared using the Wilcoxon's ranksum test. Multivariable linear regression was used to determine whether oxytocin levels differed between the two groups after correcting for potential confounders. Age, sex, percent predicted forced expiratory volume in one second, and inhaled corticosteroid dose were added into the model with disease state one at a time to determine if they altered the effect of disease on oxytocin levels.

\section{Cytosolic free calcium}

To further determine whether changes in receptor expression were associated with increased receptor function, we first tested whether oxytocin triggers calcium responses in human ASM cells and whether these responses were affected following treatment with cytokines. Calcium measurements were performed as described previously [30]. Briefly, growth-arrested HASM cells stimulated with $50 \mathrm{ng} / \mathrm{ml}$ IL-13 for $24 \mathrm{hr}$ were loaded with $3 \mu \mathrm{M}$ Fura-2/AM in HEPES buffer and resuspended (at $10^{6}$ cells $/ \mathrm{ml}$ ) in $1-\mathrm{cm}$ quartz cuvettes. After preincubating at $37^{\circ} \mathrm{C}$ for $2 \mathrm{~min}$ with gentle stirring, changes in Fura fluorescence were measured with a PTI fluorimeter (Photon Technology International, Inc.) after addition of oxytocin (0.1-1 mM). Thrombin or bradykinin was used as positive controls 
as these agonists have previously shown to increase calcium mobilization in HASM cells [31].

\section{Measurement of contractile responses}

Whether oxytocin induces contractile responses in airway smooth muscle has not been tested. Based on the oxytocin ability to trigger calcium responses in cultured ASM cells, we next investigate whether oxytocin also stimulates contractile responses using two different experimental approaches:

\section{(1) Isometric force generation}

As described in our previous reports [32-35], tracheal smooth muscle reactivity was analyzed using temperature-controlled $\left(37^{\circ} \mathrm{C}\right)$ myographs (Organ Bath Model 700MO, J.P. Trading, Aarhus, Denmark) containing 5 $\mathrm{ml}$ of Krebs-Henseleit (K-H) $(118 \mathrm{NaCl}, 4.7 \mathrm{KCl}, 1.2$ $\mathrm{KH}_{2} \mathrm{PO}_{4}, 11.1$ dextrose, $1.2 \mathrm{MgSO}_{4}, 2.8 \mathrm{CaCl}_{2}$ and 25 $\mathrm{NaHCO}_{3}$ ) that was continuously aerated with a $5 \% \mathrm{CO}_{2}$ and $95 \% \mathrm{O}_{2}$ mixture; a $\mathrm{pH}$ of 7.40-7.45 was established for the entire duration of the experiments. The tracheal segments were mounted on two L-shaped metal pins. One pin was connected to a force-displacement transducer for continuous recording of isometric tension by the Chart software (AD Instruments Ltd., Hastings, UK). The other pin is directly connected to a displacement device, allowing the adjustment of the basal tensions that were set at approximately $0.5 \mathrm{~g}$ and stimulated with agonists after attainment of steady-state tension. All values were expressed as means \pm SE. Student's unpaired t-test was used to compare the effect of oxytocin or carbachol. A P value of $<0.05$ was considered significant.

\section{(2) Precision cut lung slices (PCLS)}

PCLS was performed as described previously [36,37]. Female Balb $\mathrm{C}$ mice (8-10 weeks) were euthanized by an overdose to carbon dioxide gas. The trachea was exposed and a cannula was inserted. Lungs were inflated using $1.0 \mathrm{ml}$ of a $2 \%(\mathrm{w} / \mathrm{v})$ low melting point agarose solution followed by a $0.1 \mathrm{ml}$ air bolus to force the agarose out of the airways and into the alveoli. The inflated lungs were dissected from the thoracic cavity and mounted in agarose using the tissue embedding kit (Alabama Research \& Development, Model \# MD2200). Cores were placed into the slicer (Krumdieck Tissue Slicer, Alabama Research \& Development, Model \# MD4000) and the speed was set to produce slices at approximately 1 per 30 seconds (thickness: $250 \mu \mathrm{m}$ ). Suitable airways on slices were selected on the basis of the following criteria: presence of a full smooth muscle wall (i.e., cut perpendicular to direction of airway), presence of beating cilia to eliminate blood vessels, and unshared muscle walls at airway branch points to eliminate possible counteracting contractile forces. Slices were then transferred to incubating buffer and incubated at $37^{\circ} \mathrm{C}$ on a rotating platform. Trauma caused by tissue slicing contracts the airway presumably by the release of mediators. The incubation buffer was therefore changed every $30 \mathrm{~min}$ for $4 \mathrm{hr}$ to remove any constrictor mediators released from the tissue that prevents the airway from relaxing to baseline, and then every $24 \mathrm{hr}$ as indicated. On the next day (18 hr later), slices were washed again with fresh medium.

Lung slices were then placed in a 12-well plate in 1.0 $\mathrm{ml}$ assay buffer. The airway was located using a microscope (Nikon ECLIPSE, Model \# TE2000-U; Mag.: x100) and the slice was held in place using a platinum weight with nylon attachments. Media was added for baseline measurements. The airway was positioned so a live video feed (Evolution QEi; Model \# 32- 0074A-130 video-recorder) could be viewed. A baseline image was taken followed by the administration of the $1.0 \mu \mathrm{M}$ concentration of oxytocin. Images were collected after 4 min or after no further contraction. The airways were then administered a $1.0 \mu \mathrm{M}$ concentration of carbachol followed by the collection of images.

Airway lumen size was measured using a macro written within Image Pro-Plus (version 6.0) software (Media Cybernetics) and given in units of $\mu \mathrm{m} 2$. After functional studies, the area of each airway at baseline and at the end of each dose of agonist was calculated using the same macro written within Image Pro-Plus software. Data were plotted as percentage contractions (100 - (\% Initial Airway Size)) for each agonist. Data were expressed as means \pm SEM. Statistical difference was shown by using a paired $t$ test.

\section{Results}

\section{Expression of total mRNA for the oxytocin receptor}

Primary human airway smooth muscle monolayers from healthy donors were cultured with IL-13 or a naturally occurring mutant form IL-13R130Q for $0,6 \mathrm{hr}$ or $18 \mathrm{hr}$ at $50 \mathrm{ng} / \mathrm{ml}$ after serum deprivation for $24 \mathrm{hr}$. Total RNA was isolated, reverse transcribed and used in real time PCR analysis for oxytocin receptor which revealed that oxytocin receptor was expressed in primary airway smooth muscle cells, and the expression was increased by IL-13 ( 2 fold) and by IL-13R130Q ( 2 fold) at $6 \mathrm{hr}$ and approximately 3.5 fold at $18 \mathrm{hr}$ (Figure 1A). In parallel, airway smooth muscle cells were also treated with tumor necrosis factor alpha (TNF $\alpha$ ) for $0,6 \mathrm{hr}$ or $18 \mathrm{hr}$ at $10 \mathrm{ng} / \mathrm{ml}$. Total mRNA expression for oxytocin receptor showed that TNF $\alpha$ increased expression of oxytocin receptor by approximately 5 fold at $6 \mathrm{hr}$ and 7 fold at $18 \mathrm{hr}$ as compared with that obtained from diluent-treated cells (Figure 1B).

To characterize the expression of oxytocin receptor across various tissues, real time PCR was performed to detect oxytocin receptor in normal tissues. The highest 


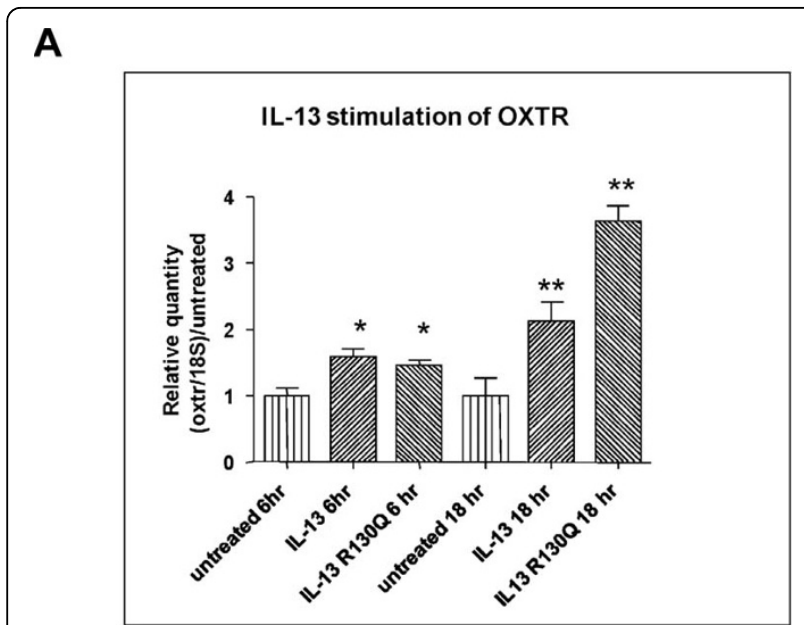

B

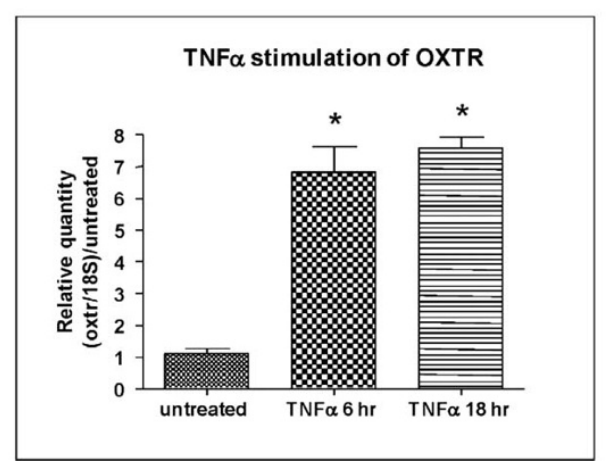

Figure 1 Real time PCR $\left(\operatorname{TaqMan}^{\circledR}\right.$ ) analysis showing the quantity of oxytocin receptor normalized to $18 \mathrm{~S}$ and relative to untreated in primary human airway smooth muscle cells from normal donors when treated with IL-13 or IL-13R130Q (A) and TNF $\alpha$ (B) for $6 \mathrm{hr}$ and $18 \mathrm{hr}$. * Significant difference between treated and untreated conditions ( $p<0.05$ ), but not between the two treated conditions; ${ }^{* *}$ Significant difference between treated and untreated conditions ( $p<0.05$ ), as well as between the two treated conditions.

expression was detected in breast, followed by male caval vein and penis and uterus. The basal expression level was modest for the majority of normal tissues, including normal lung. These data suggest that OXTR expression in lung occurs at low levels in the basal state (Table 1).

\section{Cytokines increase oxytocin receptor expression in HASMCs}

In order to confirm the stimulatory effect of IL-13 and TNF $\alpha$ on oxytocin receptor at the protein level, flow cytometry was performed. As shown in Figure 2, expression of oxytocin receptor was significantly augmented in cells treated with either TNF $\alpha(10 \mathrm{ng} / \mathrm{ml})$ or IL-13 $(50$ $\mathrm{ng} / \mathrm{ml}$ ) for $24 \mathrm{hr}$ with a net $43 \pm 2.8 \%$ and $16.7 \pm 6.8 \%$ increase over basal, respectively $(\mathrm{P}<0.05, \mathrm{n}=9)$. Increases in oxytocin receptor proteins by TNF $\alpha$ or IL13 correlated with changes in total mRNA levels
(Figures 1A and 1B), suggesting that inflammatory cytokines possibly upregulate oxytocin receptor in HASMCs at the transcriptional level.

\section{Inflammatory cytokines modulate oxytocin-evoked calcium mobilization}

We next determined whether oxytocin receptors expressed on the surface of HASM cells were functional by assessing oxytocin effects on mobilization of intracellular calcium and whether oxytocin calcium responses were modulated by cytokines. As shown in Figure. 3A and $3 \mathrm{~B}$, oxytocin $(100 \mathrm{nM})$ induced a rapid increase in intracellular calcium concentration reaching $30 \pm 11 \mathrm{nM}$ that was significantly enhanced in IL-13-treated cells to $117 \pm 18 \mathrm{nM}(\mathrm{n}=9, \mathrm{P}<0.05)$ (Figure 4). Interestingly, although TNF $\alpha$ was more effective in increasing oxytocin receptor expression, oxytocin had no modulating effect on oxytocin-induced calcium responses in HASM cells. In contrast, TNF $\alpha$ significantly increased calcium signals in response to bradykinin from $454 \pm 24 \mathrm{nM}$ to $660 \pm 59$ $\mathrm{nM}(\mathrm{n}=3$ different cell lines, $\mathrm{P}<0.05)$.

\section{Oxytocin induces force generation and airway narrowing} in murine tracheal ring and lung slices, respectively

We have previously shown that isolated murine tracheal rings represent an interesting ex vivo model to investigate the factors and the mechanisms that modulate airway smooth muscle responsiveness [32-34]. As shown in Figure 4 , oxytocin elicited a rapid contractile response in murine tracheal rings $(0.4 \pm 0.06 \mathrm{~g}, \mathrm{n}=8, \mathrm{P}<0.05)$. The contractile response induced by oxytocin was sustained for $30 \mathrm{~min}$ (data not shown) but was much less robust as compared with that induced by carbachol, reaching $25 \%$ when expressed as an percentage (\%) of the responses induced by $10^{-5} \mathrm{M}$ carbachol $(1.57 \pm 0.1 \mathrm{~g})$. These data show that oxytocin is an effective contractile agonist in the airways.

We also found that murine intra-pulmonary airways narrowed $16.2 \pm 4.1 \%$ from baseline after the administration of $1.0 \mu \mathrm{M}$ oxytocin. In separate experiments, the effects of oxytocin on carbachol-mediated force generation were examined. The airway was contracted maximally to oxytocin, and then carbachol was added. Carbachol further narrowed the airway to $62.4 \pm 5.0 \%$ from baseline. Thus, the oxytocin contraction was $26 \%$ as effective as carbachol but does suggest that oxytocin has a contractile effect on airway smooth muscle in murine intra-pulmonary airways (Figure 5).

\section{Oxytocin levels in BAL samples from asthmatic and healthy subjects}

The goal of these experiments was to assess whether oxytocin levels are determined and detected in the BAL of healthy subjects and those with asthma. As shown in Table 2, oxytocin levels are present in BAL fluid from 
Table 1 The expression of oxytocin receptor across various tissues as measured by real time PCR. The expression is normalized to $18 \mathrm{~S}$.

\begin{tabular}{|c|c|c|c|}
\hline Total RNA Human & $18 \mathrm{~S}$ Qty adjusted & Total RNA Human & 18 S Qty adjusted \\
\hline Adrenal, Female, Adult & 1 & Kidney, Male, Adult & 2.7 \\
\hline Aorta, Female, Fetal & 3.1 & Kidney, Male, Fetal & 4.4 \\
\hline Bladder, Male, Adult & 3.4 & Larynx, Male, Adult & 5.8 \\
\hline Bladder, Female, Fetal & 5.4 & Larynx, Male, Adult & 3.3 \\
\hline Bladder, Male, Fetal & 7.2 & Liver, Female, Adult & 0.44 \\
\hline Brain, Female, Fetal & 10.3 & Liver, Female, Fetal & 1.3 \\
\hline Brain, Male, Adult & 9.0 & Liver, Male, Adult & 0.6 \\
\hline Brain, Male, Fetal & 2.6 & Liver, Male, Fetal & 2 \\
\hline Brain, Occipital Cortex, Male, Adult & 11.6 & Lung, Female, Adult & 1.9 \\
\hline Brain, Parietal Cortex, Male, Adult & 8.3 & Lung, Female, Fetal & 1.8 \\
\hline Breast, Female, Adult & 160.2 & Lung, Male, Adult & 3.5 \\
\hline Caval Vein, Male, Adult & 25.3 & Lung, Male, Fetal & 8.3 \\
\hline Cervix, Female, Adult & 1.7 & Lymph Node, Male, Adult & 6.6 \\
\hline Colon, Ascending, Female, Adult & 12.4 & Ovary, Female, Adult & 11.5 \\
\hline Colon, Descending, Female, Adult & 1 & Pancreas, Male, Adult & 0.28 \\
\hline Colon, Female, Fetal & 2.6 & Parotid, Female, Adult & 0.41 \\
\hline Colon, Male, Adult & 3.2 & Penis, Male, Adult & 25.3 \\
\hline Colon, Male, Fetal & 1.9 & Pericardium, Male, Adult & 2.7 \\
\hline Heart, Female, Adult & 0.16 & Placenta, Adult, Female & 6 \\
\hline Heart, Female, Fetal & 12 & Prostate, Male, Adult & 4.2 \\
\hline Heart, Left Atrium, Male, Adult & 0.86 & Rectum, Male, Adult & 0.78 \\
\hline Heart, Male, Adult & 0.33 & Skeletal Muscle, Female, Fetal & 1.8 \\
\hline Kidney, Female, Fetal & 5.7 & Skeletal Muscle, Male, Adult & 0.2 \\
\hline Kidney, Female, Adult & 3.1 & Skeletal Muscle, Male, Fetal & 2.4 \\
\hline Skin, Female, Adult & 0.92 & Testes, Male, Adult & 8.6 \\
\hline Skin, Female, Fetal & 2.6 & Thymus, Male and Female, Fetal & 1.6 \\
\hline Skin, Male, Adult & 1 & Thymus, Male, Adult & 1.7 \\
\hline Spleen, Female, Adult & 1.8 & Thyroid, Female, Adult & 1.3 \\
\hline Spleen, Female/Male pooled, Fetal & 7.7 & Tongue, Male/Female, Adult & 1.9 \\
\hline Spleen, Male, Adult & 2.4 & Trachea, Female, Adult & 5.5 \\
\hline Stomach, Female, Adult & 0.18 & Uterus, Female, Adult & 13.7 \\
\hline Stomach, Female, Fetal & 6.2 & Colon, Female, Adult (Top) & 3 \\
\hline Stomach, Male, Adult & 0.6 & Larynx, Male, Adult (Normal) & 5.5 \\
\hline Stomach, Male, Fetal & 3.9 & & \\
\hline
\end{tabular}

both normal subjects and those with asthma ( $\mathrm{n}=10$ in each group) but no significant changes were detected between these cohorts. Further, there was no gender differences in oxytocin levels observed. Oxytocin levels in sputum supernatant did not differ between asthmatics and healthy control subjects (median oxytocin levels $13.2 \mathrm{mcg} / \mathrm{ml}$ and $12.4 \mathrm{mcg} / \mathrm{ml}$, respectively, $\mathrm{p}=0.97)$. Multivariable analyses confirmed that there was no significant difference in oxytocin levels even after controlling for age, sex, percent predicted forced expiratory volume in one second, and inhaled corticosteroid dose.

\section{Discussion}

Oxytocin regulates gonadal function such as labor-associated uterine contractions and milk discharge during lactation [1], but the role of oxytocin in other tissues remains unexplored. Evidence shows that the incidence of asthma switches at puberty from male to female predominance, and in adult asthma the ratio is about 2:1 in favor of women $[38,39]$ and that asthma worsens in about $30 \%$ of pregnant women [9]. Whether oxytocin plays a role in determining gender susceptibility to asthma remains unknown. Our present study demonstrates the existence of functional oxytocin receptors on HASMCs and their regulation by pro-inflammatory cytokines known to be involved in asthma pathogenesis. Further, we report that oxytocin induced force generation and contractile responses in isolated murine tracheal rings [32-34] and lung slices [40,41]. These data suggest that expression of oxytocin receptor (OXTR) on 


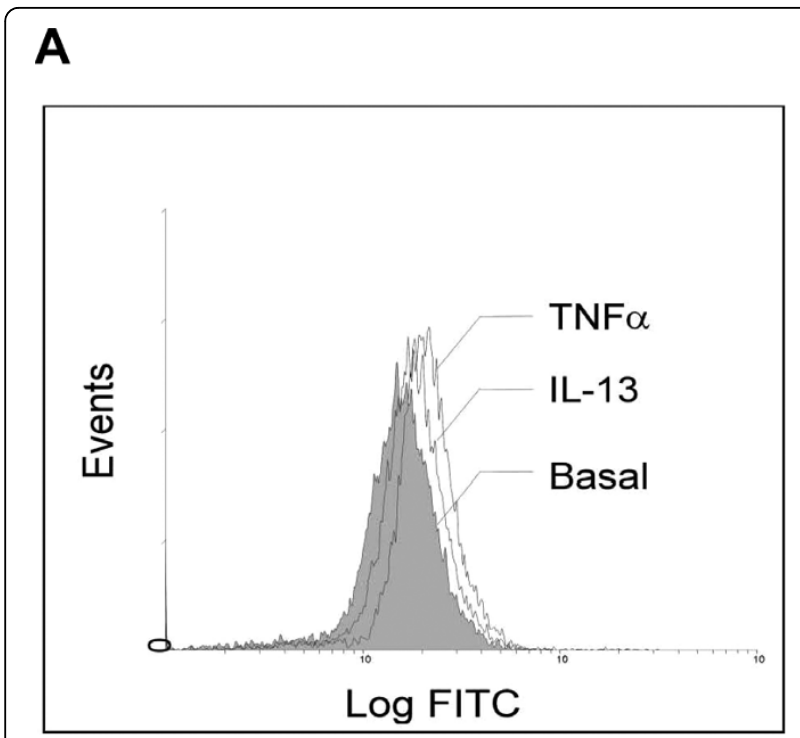

B

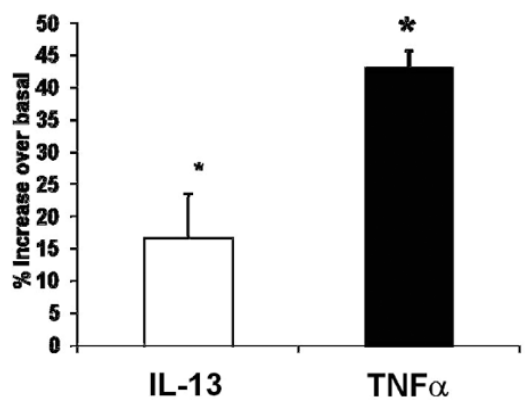

Figure 2 (A) Representative flow-cytometric analysis of oxytocin receptor expression in basal and HASM cells exposed to $50 \mathrm{ng} / \mathrm{ml} \mathrm{IL-13}$ or $10 \mathrm{ng} / \mathrm{ml}$ TNF $\alpha$ for $24 \mathrm{hr}$. (B) Graphical representation of the data as percentage increase in mean fluorescence intensity over basal. ${ }^{*} \mathrm{P}<0.05$ as compared with untreated cells, $n=9$.

HASMCs can be differentially modulated by inflammatory cytokines in HASMCs, a mechanism that may contribute to the altered airway responsiveness observed in asthma assuming that such receptor changes would occur in vivo.

The study of the molecular mechanisms regulating the expression of oxytocin receptor remains complex $[42,43]$. Most studies that attempt to elucidate the transcriptional regulation of oxytocin receptors have been performed in myometrial and uterine cells. Using these models, investigators found that OXTR expression was downregulated by IL-1 $\beta$, IL- 6 but not by TNF $\alpha[44,45]$. Others found that lysophospholipids increased translation of oxytocin receptor possibly as a consequence of increased mRNA stability [46]. Our report is the first to demonstrate that expression of oxytocin receptor is

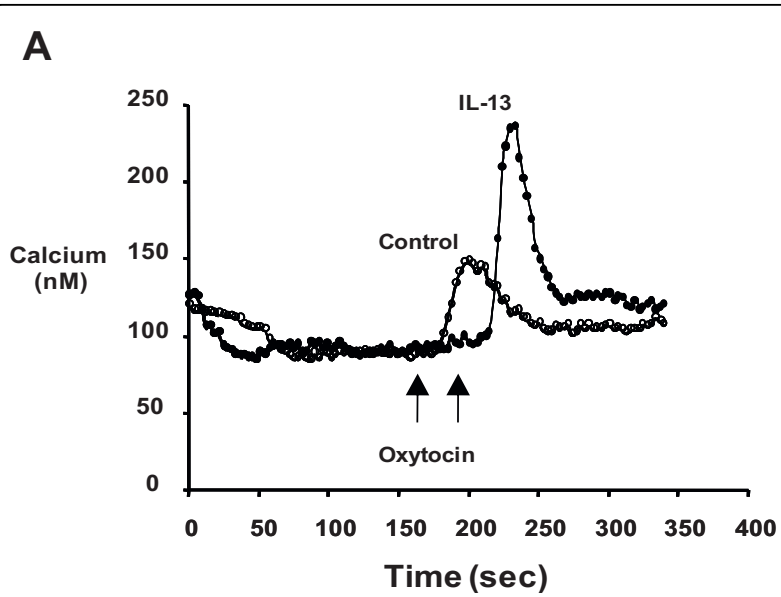

B

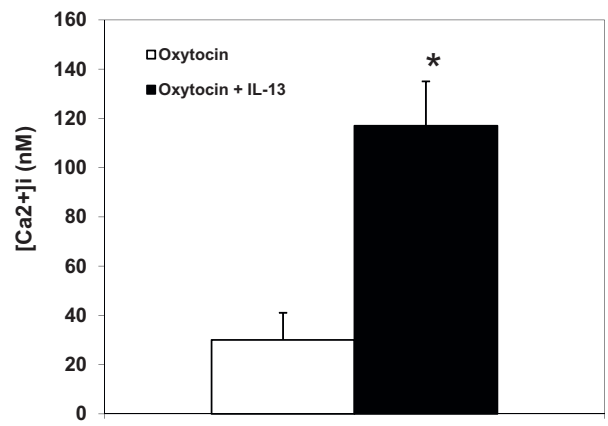

Figure 3 Effect of IL-13 on oxytocin-evoked cytosolic free $\mathrm{Ca}^{2+}$ concentration $\left(\left[\mathrm{Ca}^{2+}\right]_{\mathrm{i}}\right)$. IL-13 $(50 \mathrm{ng} / \mathrm{ml})$ was pre-incubated for 24 $\mathrm{hr}$ before cells were exposed to $100 \mathrm{nM}$ oxytocin. (A) Typical $\mathrm{Ca}^{2+}$ traces from cells incubated in the absence or presence of IL-13. (B) Graphical representation of values for the $\mathrm{Ca}^{2+}$ peak phase from cells incubated in the absence or presence of IL-13. Results are expressed as the net increase in $\left[\mathrm{Ca}^{2+}\right]_{i}$ over basal (unstimulated) levels. Values are means \pm SE of 3 separate experiments and are significantly different from oxytocin only control $(P<0.01)$. TNF $\alpha$ did not have a modulatory effect on oxytocin-induced calcium response in these cells. increased in HASMCs treated with pro-inflammatory cytokines, either TNF $\alpha$ or IL-13. An increased gene transcription was detected by the real time PCR data demonstrating a rapid effect of these cytokines on oxytocin receptor expression. In addition, both TNF $\alpha$ and IL-13 up-regulated receptor expression at the protein level with a 7 fold and 3.5 fold increase over basal, respectively. Unexpectedly, IL-13, but not TNF $\alpha$, enhanced oxytocin-evoked calcium responses in HASMCs. The mechanisms responsible for the differential effects of TNF $\alpha$ and IL13 to enhance oxytocinevoked calcium responses remain unclear. This is surprising given evidence that IL-13 and TNF $\alpha$ comparably enhance calcium signals induced by bradykinin and acetylcholine $[19,34,47,48]$. Our data does support the hypothesis that TNF and IL-13 have disparate effects on 


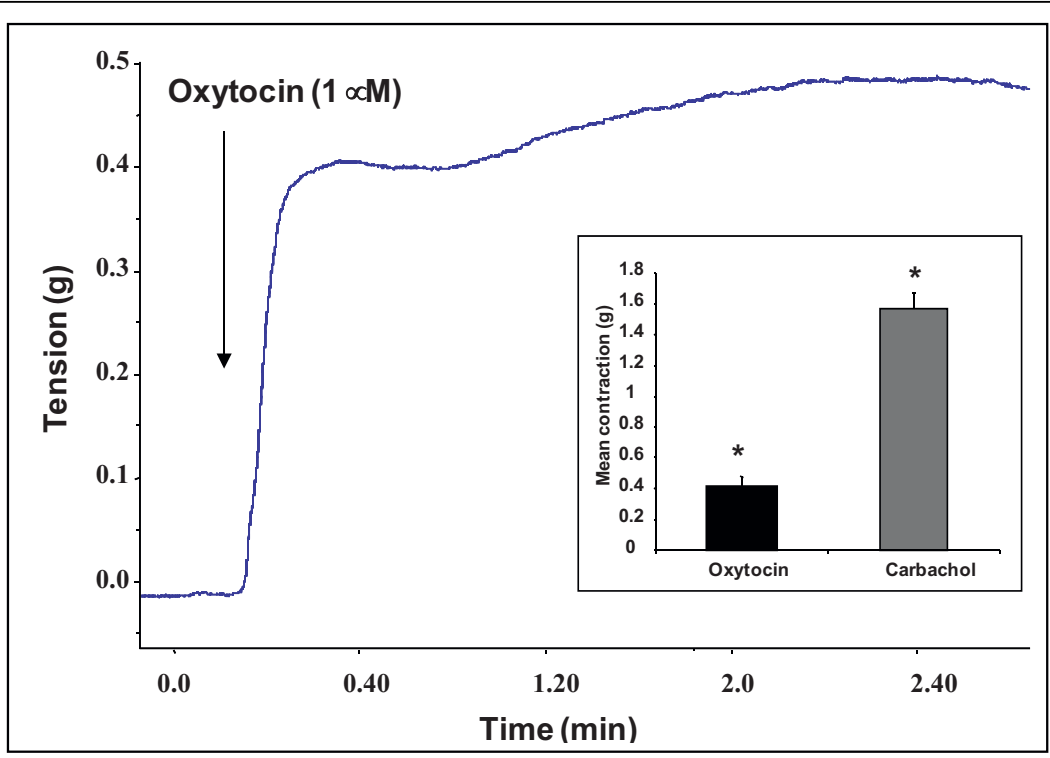

Figure 4 Representative trace showing the contractile response induced by oxytocin in isolated murine tracheal rings. Similar responses were observed in eight different tracheal rings. The insert shows the contractile responses expressed as means \pm SEM from 8 different tracheal rings stimulated with $1 \mu \mathrm{M}$ oxytocin or $10 \mu \mathrm{M}$ carbachol ( $p<0.05$ compared to basal values, statistical significance using ANOVA).

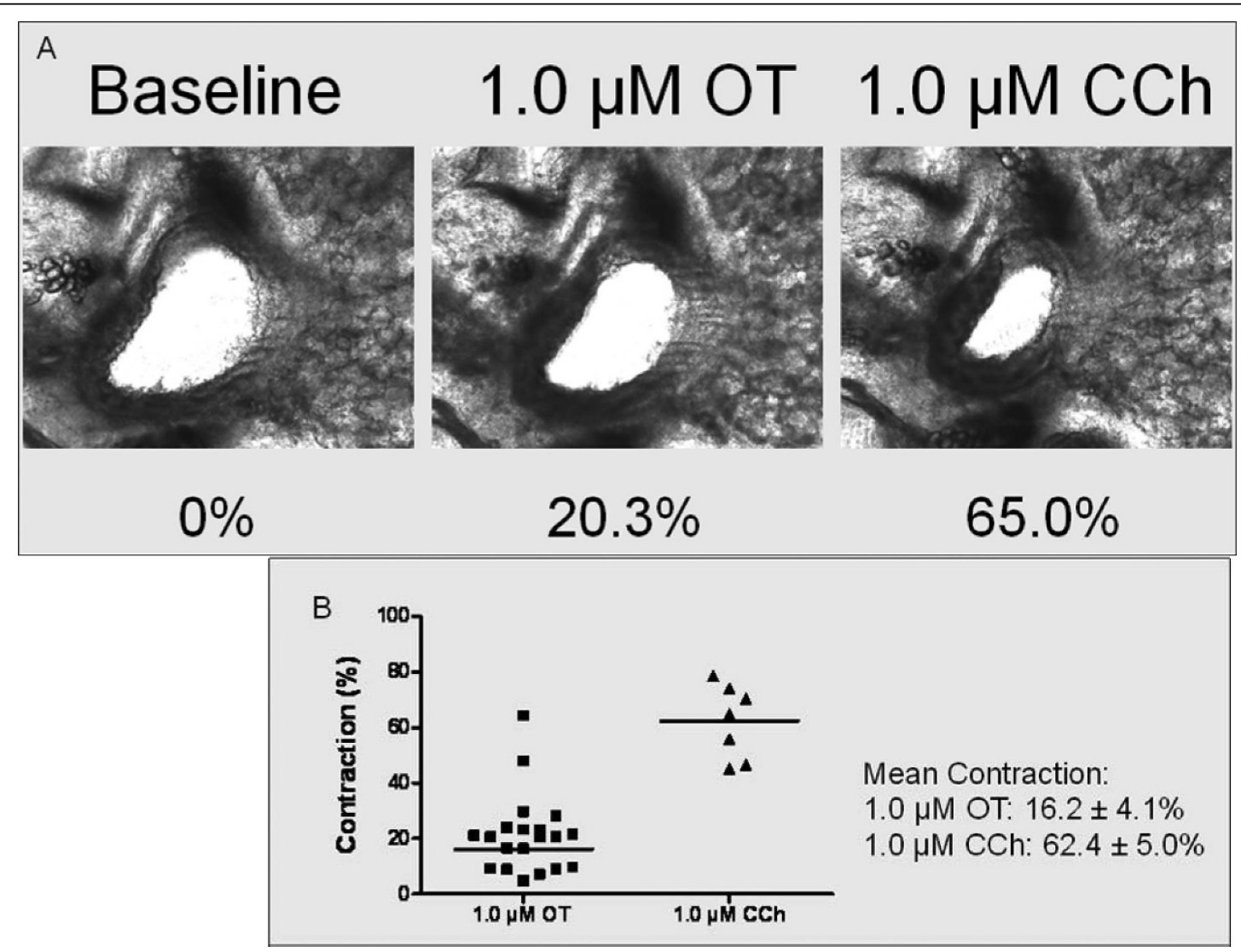

Figure 5 Effect of oxytocin (OT) on murine intra-pulmonary airways with respect to a sub-maximal dose of carbachol (CCh). (A) Representational images show a murine airway at baseline (0\% contraction), following $1.0 \mu \mathrm{M}$ OT (20.3\%) and $1.0 \mu \mathrm{M}$ CCh (65.0\%). (B) Maximum contraction of individual airways following OT and CCh. Mean \pm SEM values of the data shown. 
Table 2 Oxytocin levels in BAL samples from asthmatic and healthy subjects

\begin{tabular}{|c|c|c|c|c|c|c|c|c|c|}
\hline Asthmatics & Age & FEV1\%pred & FEV1/FVC & $\begin{array}{l}\text { Bronchodilator } \\
\text { response (\% change } \\
\text { from baseline) }\end{array}$ & $\begin{array}{c}\mathrm{PC} 20(\mathrm{mg} / \\
\mathrm{dl})\end{array}$ & Gender & GINA & $\begin{array}{c}\text { Inhaled } \\
\begin{array}{c}\text { Corticosteroid BDP } \\
\text { equivalent }\end{array} \\
\end{array}$ & Oxytocin \\
\hline 1 & 31 & 120 & 82 & 3 & 0.1 & M & 1 & 0 & 14.0 \\
\hline 2 & 47 & 96 & 73 & 16 & 1.6 & $F$ & 1 & 0 & 12.9 \\
\hline 3 & 40 & 69 & 60 & 15 & 0.7 & $M$ & 1 & 0 & 12.4 \\
\hline 4 & 43 & 86 & 80 & 8 & 1.6 & M & 1 & 0 & 13.4 \\
\hline 5 & 52 & 72 & 68 & 12 & 2.4 & $F$ & 1 & 0 & 21.3 \\
\hline 6 & 28 & 90 & 85 & 6 & 0.6 & $F$ & 1 & 0 & 15.0 \\
\hline 7 & 31 & 80 & 72 & 15 & 3.2 & $M$ & 1 & 0 & 10.1 \\
\hline 8 & 41 & 68 & 66 & 18 & 1.4 & $F$ & 1 & 0 & 10.9 \\
\hline 9 & 36 & 86 & 83 & 6 & 0.2 & $F$ & 2 & 400 & 19.5 \\
\hline 10 & 68 & 97 & 60 & 15 & 0.5 & $\mathrm{~F}$ & 2 & 400 & 9.5 \\
\hline Mean \pm SD & $41.7 \pm 11.9$ & $86.4 \pm 15.8$ & $72.9 \pm 9.4$ & $11.4 \pm 5.2$ & $1.23 \pm 1.0$ & & & & $13.9 \pm 3.9$ \\
\hline \multicolumn{10}{|l|}{ Controls } \\
\hline 1 & 26 & 96 & 83 & 0 & 32 & M & 0 & 11.7 & \\
\hline 2 & 30 & 112 & 88 & 0 & 32 & $\mathrm{~F}$ & 0 & 12.4 & \\
\hline 3 & 43 & 122 & 82 & 0 & 32 & $\mathrm{~F}$ & 0 & 15.6 & \\
\hline 4 & 55 & 100 & 78 & 1.7 & 32 & $\mathrm{~F}$ & 0 & 12.3 & \\
\hline 5 & 61 & 97 & 71 & -4.8 & 32 & $F$ & 0 & 11.4 & \\
\hline 6 & 43 & 125 & 85 & 0 & 32 & M & 0 & 17.4 & \\
\hline 7 & 47 & 108 & 85 & 0 & 32 & M & 0 & 12.3 & \\
\hline 8 & 49 & 102 & 88 & 0 & 32 & M & 0 & 15.6 & \\
\hline 9 & 45 & 106 & 78 & 4.3 & 32 & $\mathrm{~F}$ & 0 & 17.1 & \\
\hline 10 & 23 & 94 & 80 & 3.2 & 32 & $\mathrm{~F}$ & 0 & 12.2 & \\
\hline Mean \pm SD & $42.2 \pm 12.4$ & $106.2 \pm 10.7$ & $81.8 \pm 5.2$ & $0.44 \pm 2.4$ & $32 \pm 0$ & & & & $13.8 \pm 2.3$ \\
\hline
\end{tabular}

OXTR expression and that agonists with less efficacy at inducing calcium mobilization may be enhanced by increases in receptor expression rather than by processes that amplify downstream pro-contractile signaling pathways. Accordingly, we and others also reported that changes in bradykinin receptor expression in part explained the enhancing effects of cytokines (TNF $\alpha$ or IL-1 $\beta$ ) on agonist-evoked calcium responses [49,50]. In some but not all instances, modulation of receptor expression may not correlate with receptor function in ASM cells. In previous reports, we and others found that although calcium signals to acetycholine were significantly increased by TNF $\alpha$, muscarinic receptor density were significantly reduced in TNF $\alpha$-treated cells $[51,52]$. Collectively, these data suggest that cytokineinduced changes in receptor function may be uncoupled from cell surface receptor density. Additionally, signaling pathways such as alterations in calcium sensitization could also contribute to the observed differences in cytokine-induced agonist responsiveness but such mechanisms require further study.
We show that oxytocin receptors are expressed on HASMCs and cytokines modulate receptor expression [48]. In myometrium cells, TNF $\alpha$ enhanced oxytocininduced calcium transients [20]. Whether TNF effects were due to alterations in receptor expression was not addressed. These investigators, however, found that CD38 played a critical role in the enhanced oxytocininduced calcium responses in myometrium cells. Interestingly, both TNF $\alpha$ and IL-13 also upregulated CD38 expression and function in HASMCs [48,53-56]. Because IL-13, but not TNF $\alpha$, enhanced oxytocin calcium responses in HASMCs, our findings possibly suggest that both CD38-dependent and independent pathways may contribute to cytokine-induced alterations in oxytocin responses.

Using two ex vivo models to study airway responsiveness, namely, isolated tracheal rings [35] and mouse lung slices $[40,41]$, we found that oxytocin induced ASM contraction and airway narrowing, suggesting that oxytocin serves as a bronchoconstrictor. Whether these responses, which are modest in magnitude compared to 
those induced by carbachol, are clinically relevant remains unknown. Our study, however, shows that these bronchoconstrictor responses induced by oxytocin were dramatically increased by IL13. However, we failed to detect any effects of IL-13 on oxytocin-evoked contractile responses (Amrani et al., unpublished observations). The reasons explaining the discordance observed between IL-13 effects on cultured cells and on ex vivo tissue remains unexplained but could reflect that IL-13 effects in complex tissue provides negative homeostatic effects that dampens IL13's ability to enhance oxytocininduced bronchoconstriction. Alternatively, the diffusing barrier of the tissue thickness mitigates the ability of IL13 and/or oxytocin to stimulate their cognate receptors. Accordingly, contractile responses to oxytocin could be modulated by effects on airway epithelial cells and/or vascular endothelium [16] or by subsequent production of relevant factors such as nitric oxide [43]. Further studies are needed to address whether IL-13 modulates oxytocin effects in other lung cells.

Given our observations that oxytocin induced airway smooth muscle contraction and that cytokines increased expression of the receptor, we characterized whether BAL fluid derived from healthy subjects as well as subjects with asthma had detectable oxytocin levels. Our studies revealed that detectable oxytocin levels were found in the BAL fluid in both cohorts; however, in stable asthma, there was no increase in oxytocin levels in BAL fluid. We postulate that the mechanism by which oxytocin may play a role in asthma in acute exacerbations concerns enhanced vascular permeability into tissue where the receptor number in ASM but not the ligand are markedly increased. To address this hypothesis, OXTR expression in ASM tissue derived from subjects with acute exacerbation would be required but such studies are beyond the scope of the current study.

In summary, our report provides the first evidence of a contractile role of oxytocin in the airways. Future studies will address the nature of the common transcription factors as well as signaling pathways by which both cytokines regulate the transcription of the oxytocin receptor gene. Since gender disparity in asthma is well recognized, studies could also address whether differential OXTR expression in the airways between men and women in part explains gender differences in asthma prevalence and morbidity or whether differential OXTR expression mediates asthma morbidity in pregnancy.

\section{Acknowledgements}

R01 HL080676, R01 HL064063, R01 HL081824 and R01 HL077735 from the National Heart, Lung, and Blood Institute, National Institutes of Health; P30 ES013508 from the National Institute of Environmental Health Sciences.

\section{Author details}

'Centocor Research \& Development Inc., 200 Great Valley Parkway, Malvern, PA 19355, USA. ${ }^{2}$ Pulmonary, Allergy and Critical Care Division, Department of Medicine, University of Pennsylvania, TRL Suite 1200, 125 South 31st Street, Philadelphia, PA 19104, USA. ${ }^{3}$ Therakos, 437 Creamery Way, Exton, PA 19341. USA. ${ }^{4}$ Institute for Lung Health and Department of Infection, Immunity and Inflammation, University of Leicester, UK.

\section{Authors' contributions}

FS, CH, KI, VL performed the PCR assays, DJ, SK, HB did the calcium experiments, contractility studies and flow cytometry assays, respectively. PRP carried out the PCLS. HZ performed the ELISA in the BAL samples. SS and $C B$ provided the BAL samples. YA, FS, DG, LL, RAP participated in the design and coordination. YA, FS, RAP conceived the study and wrote the manuscript. All authors read and approved the final masniscript.

\section{Competing interests}

The authors declare that they have no competing interests.

Received: 22 March 2010 Accepted: 29 July 2010

Published: 29 July 2010

\section{References}

1. Gimpl G, Fahrenholz F: The oxytocin receptor system: structure, function, and regulation. Physiol Rev 2001, 81(2):629-683.

2. Kimura T, Takemura M, Nomura S, Nobunaga T, Kubota Y, Inoue T, Hashimoto K, Kumazawa I, Ito Y, Ohashi K, et al: Expression of oxytocin receptor in human pregnant myometrium. Endocrinology 1996, 137(2):780-785.

3. Barone F, Genazzani AA, Conti A, Churchill GC, Palombi F, Ziparo E, Sorrentino V, Galione A, Filippini A: A pivotal role for CADPR-mediated Ca2 + signaling: regulation of endothelin-induced contraction in peritubular smooth muscle cells. Faseb J 2002, 16(7):697-705.

4. Holgate ST: The epidemic of allergy and asthma. Nature 1999, 402(6760 Suppl):B2-4.

5. Barnes PJ: Immunology of asthma and chronic obstructive pulmonary disease. Nat Rev Immunol 2008, 8(3):183-192.

6. Lukacs NW, Strieter RM, Chensue SW, Widmer M, Kunkel SL: TNF-alpha mediates recruitment of neutrophils and eosinophils during airway inflammation. J Immunol 1995, 154(10):5411-5417.

7. Busse WW, Coffman RL, Gelfand EW, Kay AB, Rosenwasser L: Mechanisms of persistent airway inflammation in asthma. A role for T cells and T-cell products. Am J Respir Crit Care Med 1995, 152(1):388-393.

8. Murphy VE, Gibson P, Talbot PI, Clifton VL: Severe asthma exacerbations during pregnancy. Obstet Gynecol 2005, 106(5 Pt 1):1046-1054.

9. Murphy VE, Gibson PG, Smith R, Clifton VL: Asthma during pregnancy: mechanisms and treatment implications. Eur Respir J 2005, 25(4):731-750.

10. Barr RG, Wentowski CC, Grodstein F, Somers SC, Stampfer MJ, Schwartz J, Speizer FE, Camargo CA Jr: Prospective study of postmenopausal hormone use and newly diagnosed asthma and chronic obstructive pulmonary disease. Arch Intern Med 2004, 164(4):379-386.

11. Troisi RJ, Speizer FE, Willett WC, Trichopoulos D, Rosner B: Menopause, postmenopausal estrogen preparations, and the risk of adult-onset asthma. A prospective cohort study. Am J Respir Crit Care Med 1995, 152(4 Pt 1):1183-1188.

12. Townsend EA, Thompson MA, Pabelick CM, Prakash YS: Rapid effects of estrogen on intracellular $\mathrm{Ca} 2+$ regulation in human airway smooth muscle. Am J Physiol Lung Cell Mol Physiol 298(4):L521-530.

13. Jankowski M, Bissonauth V, Gao L, Gangal M, Wang D, Danalache $B$, Wang Y, Stoyanova E, Cloutier G, Blaise G, et al: Anti-inflammatory effect of oxytocin in rat myocardial infarction. Basic Res Cardiol 105(2):205-218.

14. Nation DA, Szeto A, Mendez AJ, Brooks LG, Zaias J, Herderick EE, Gonzales J, Noller CM, Schneiderman N, McCabe PM: Oxytocin attenuates atherosclerosis and adipose tissue inflammation in socially isolated ApoE-/- mice. Psychosom Med 72(4):376-382.

15. Biyikli NK, Tugtepe H, Sener G, Velioglu-Ogunc A, Cetinel S, Midillioglu S, Gedik N, Yegen BC: Oxytocin alleviates oxidative renal injury in pyelonephritic rats via a neutrophil-dependent mechanism. Peptides 2006, 27(9):2249-2257. 
16. Pequeux C, Breton C, Hagelstein MT, Geenen V, Legros JJ: Oxytocin receptor pattern of expression in primary lung cancer and in normal human lung. Lung Cancer 2005, 50(2):177-188.

17. Hirst S: Airway smooth muscle as a target in asthma. Clin Exp Allergy 2000, 30(1):54-59.

18. Halayko AJ, Amrani Y: Mechanisms of inflammation-mediated airway smooth muscle plasticity and airways remodeling in asthma. Respir Physiol Neurobiol 2003, 137(2-3):209-222.

19. Amrani Y, Tliba O, Deshpande DA, Walseth TF, Kannan MS, Panettieri RA Jr: Bronchial hyperresponsiveness: insights into new signaling molecules. Curr Opin Pharmacol 2004, 4(3):230-234.

20. Thompson M, Barata da Silva H, Zielinska W, White TA, Bailey JP, Lund FE, Sieck GC, Chini EN: Role of CD38 in myometrial Ca2+ transients: modulation by progesterone. Am J Physiol Endocrinol Metab 2004, 287(6): E1142-1148.

21. Amrani Y: Airway smooth muscle modulation and airway hyperresponsiveness in asthma: new cellular and molecular paradigms. Exp Rev Clin Immunol 2006, 2:353-364.

22. Amrani Y: TNF-alpha and calcium signaling in airway smooth muscle cells: a never-ending story with promising therapeutic relevance. Am J Respir Cell Mol Biol 2007, 36(3):387-388.

23. Akbari $O$, Stock $P$, Meyer E, Kronenberg M, Sidobre S, Nakayama T, Taniguchi M, Grusby MJ, DeKruyff RH, Umetsu DT: Essential role of NKT cells producing IL- 4 and IL-13 in the development of allergen-induced airway hyperreactivity. Nat Med 2003, 9(5):582-588.

24. Grunig G, Warnock M, Wakil AE, Venkayya R, Brombacher F, Rennick DM, Sheppard D, Mohrs M, Donaldson DD, Locksley RM, et al: Requirement for IL-13 independently of IL-4 in experimental asthma. Science 1998, 282(5397):2261-2263.

25. Venkayya R, Lam M, Willkom M, Grunig G, Corry DB, Erle DJ: The Th2 lymphocyte products IL-4 and IL-13 rapidly induce airway hyperresponsiveness through direct effects on resident airway cells. Am J Respir Cell Mol Biol 2002, 26(2):202-208.

26. Walter DM, McIntire JJ, Berry G, McKenzie AN, Donaldson DD, DeKruyff RH, Umetsu DT: Critical role for IL-13 in the development of allergen-induced airway hyperreactivity. J Immunol 2001, 167(8):4668-4675.

27. Wills-Karp M, Luyimbazi J, Xu X, Schofield B, Neben TY, Karp CL, Donaldson DD: Interleukin-13: central mediator of allergic asthma. Science 1998, 282(5397):2258-2261.

28. Graves PE, Kabesch M, Halonen M, Holberg CJ, Baldini M, Fritzsch C, Weiland SK, Erickson RP, von Mutius E, Martinez FD: A cluster of seven tightly linked polymorphisms in the IL-13 gene is associated with total serum IgE levels in three populations of white children. J Allergy Clin Immunol 2000, 105(3):506-513.

29. Amrani $Y$, Lazaar AL, Panettieri RA Jr: Up-Regulation of ICAM-1 by Cytokines in Human Tracheal Smooth Muscle Cells Involves an NF\{kappa\}B-Dependent Signaling Pathway That Is Only Partially Sensitive to Dexamethasone. J Immunol 1999, 163(4):2128-2134.

30. Amrani $Y$, Magnier C, Enouf J, Wuytack F, Bronner C: Ca2+ increase and Ca (2+)- influx in human tracheal smooth muscle cells: role of $\mathrm{Ca} 2+$ pools controlled by sarco-endoplasmic reticulum $\mathrm{Ca}(2+)$ - ATPase 2 isoform. $\mathrm{Br}$ J Pharmacol 1995, 115(7):1204-1210.

31. Amrani Y, Krymskaya V, Maki C, Panettieri RA Jr: Mechanisms underlying TNF-alpha effects on agonist-mediated calcium homeostasis in human airway smooth muscle cells. Am J Physiol 1997, 273(5):L1020-1028.

32. Chen H, Tliba O, Van Besien CR, Panettieri RA Jr, Amrani Y: Selected Contribution: TNF-\{alpha\} modulates murine tracheal rings responsiveness to $\mathrm{G}$-protein-coupled receptor agonists and $\mathrm{KCl}$. J Appl Physiol 2003, 95(2):864-872.

33. Kim JH, Jain D, Tliba O, Yang B, Jester WF Jr, Panettieri RA Jr, Amrani $Y$, Pure E: TGF-beta potentiates airway smooth muscle responsiveness to bradykinin. Am J Physiol Lung Cell Mol Physiol 2005, 289(4):L511-520.

34. Tliba O, Deshpande D, Van Besien C, Chen H, Kannan M, Panettieri RA, Amrani Y: IL-13 enhances agonist-evoked calcium signals and contractile responses in airway smooth muscle. $\mathrm{Br} J$ Pharmacol 2003, 140:1159-1162.

35. Jain D, Keslacy S, Tliba O, Cao Y, Kierstein S, Amin K, Panettieri RA Jr, Haczku A, Amrani Y: Essential role of IFNbeta and CD38 in TNFalpha- induced airway smooth muscle hyper-responsiveness. Immunobiology 2008, 213(6):499-509.

36. Cooper PR, Panettieri RA Jr: Steroids completely reverse albuterol-induced beta(2)-adrenergic receptor tolerance in human small airways. J Allergy Clin Immunol 2008, 122(4):734-740.

37. Cooper PR, Poll CT, Barnes PJ, Sturton RG: Involvement of IL-13 in Tobacco Smoke Induced Changes in the Structure and Function of Rat Intrapulmonary Airways. Am J Respir Cell Mol Biol 2009.

38. Almqvist $C$, Worm $M$, Leynaert B: Impact of gender on asthma in childhood and adolescence: a GA2LEN review. Allergy 2008, 63(1):47-57.

39. Chanez P, Wenzel SE, Anderson GP, Anto JM, Bel EH, Boulet LP, Brightling CE, Busse WW, Castro M, Dahlen B, et al: Severe asthma in adults: what are the important questions? J Allergy Clin Immunol 2007, 119(6):1337-1348.

40. Bai $Y$, Zhang M, Sanderson MJ: Contractility and Ca2+ signaling of smooth muscle cells in different generations of mouse airways. Am J Respir Cell Mol Biol 2007, 36(1):122-130.

41. Bergner A, Sanderson MJ: Airway contractility and smooth muscle $\mathrm{Ca}(2+)$ signaling in lung slices from different mouse strains. J Appl Physiol 2003, 95(3):1325-1332

42. Kimura T, Saji F, Nishimori K, Ogita K, Nakamura H, Koyama M, Murata Y: Molecular regulation of the oxytocin receptor in peripheral organs. $J \mathrm{Mol}$ Endocrinol 2003, 30(2):109-115.

43. Zingg HH, Laporte SA: The oxytocin receptor. Trends Endocrinol Metab 2003, 14(5):222-227.

44. Helmer $H$, Tretzmuller $U$, Brunbauer $M$, Kaider A, Husslein P, Knofler M: Production of oxytocin receptor and cytokines in primary uterine smooth muscle cells cultivated under inflammatory conditions. J Soc Gynecol Investig 2002, 9(1):15-21.

45. Schmid B, Wong S, Mitchell BF: Transcriptional regulation of oxytocin receptor by interleukin-1beta and interleukin-6. Endocrinology 2001, 142(4):1380-1385.

46. Jeng YJ, Soloff SL, Anderson GD, Soloff MS: Regulation of oxytocin receptor expression in cultured human myometrial cells by fetal bovine serum and lysophospholipids. Endocrinology 2003, 144(1):61-68.

47. Amrani Y, Panettieri RA Jr: Modulation of calcium homeostasis as a mechanism for altering smooth muscle responsiveness in asthma. Curr Opin Allergy Clin Immunol 2002, 2(1):39-45.

48. Deshpande DA, Dogan S, Walseth TF, Miller SM, Amrani Y, Panettieri J, Reynold A, Kannan MS: Modulation of calcium signaling by IL-13 in human airway smooth muscle: role of CD38/CADPR pathway. Am J Respir Cell Mol Biol 2004, 2003-03130C.

49. Hsu Y, Chiu C, Wang C, Chien C, Luo S, Hsiao L, Liang K, Yang C: Tumour necrosis factor-alpha enhances bradykinin-induced signal transduction via activation of Ras/Raf/MEK/MAPK in canine tracheal smooth muscle cells. Cell Signal 2001, 13(9):633-643.

50. Yang C, Chien C, Wang C, Hsu Y, Chiu C, Lin C, Luo S, Hsiao L: Interleukin1 beta enhances bradykinin-induced phosphoinositide hydrolysis and Ca2+ mobilization in canine tracheal smooth-muscle cells: involvement of the Ras/Raf/mitogen-activated protein kinase (MAPK) kinase (MEK)/ MAPK pathway. Biochem J 2001, 354(2):439-446.

51. Hotta K, Emala CW, Hirshman CA: TNF-alpha upregulates Gialpha and Gqalpha protein expression and function in human airway smooth muscle cells. Am J Physiol 1999, 276(3 Pt 1):L405-L411.

52. Amrani $Y$, Martinet N, Bronner C: Potentiation by tumour necrosis factoralpha of calcium signals induced by bradykinin and carbachol in human tracheal smooth muscle cells. Br J Pharmacol 1995, 114(1):4-5.

53. Deshpande DA, Walseth TF, Panettieri RA, Kannan MS: CD38-cyclic ADP ribosemediated $\mathrm{Ca} 2+$ signaling contributes to airway smooth muscle hyperresponsiveness. Faseb J 2003, FASEB Journal Express Article 10.1096/ fj.1002-0450fje.

54. Deshpande DA, White TA, Guedes AG, Milla C, Walseth TF, Lund FE, Kannan MS: Altered Airway Responsiveness in CD38-Deficient Mice. Am J Respir Cell Mol Biol 2005, 32(2):149-156.

55. Tliba O, Cidlowski JA, Amrani Y: CD38 expression is insensitive to steroid action in cells treated with tumor necrosis factor-alpha and interferon- 
gamma by a mechanism involving the up-regulation of the glucocorticoid receptor beta isoform. Mol Pharmacol 2006, 69(2):588-596.

56. Tliba O, Panettieri RA Jr, Tliba S, Walseth TF, Amrani Y: Tumor necrosis factor-alpha differentially regulates the expression of proinflammatory genes in human airway smooth muscle cells by activation of interferonbeta-dependent CD38 pathway. Mol Pharmacol 2004, 66(2):322-329.

doi:10.1186/1465-9921-11-104

Cite this article as: Amrani et al:: Expression and activation of the oxytocin receptor in airway smooth muscle cells: Regulation by TNF $\alpha$ and IL-13. Respiratory Research 2010 11:104.

Submit your next manuscript to BioMed Central and take full advantage of:

- Convenient online submission

- Thorough peer review

- No space constraints or color figure charges

- Immediate publication on acceptance

- Inclusion in PubMed, CAS, Scopus and Google Scholar

- Research which is freely available for redistribution

Submit your manuscript at www.biomedcentral.com/submit
C Biomed Central 